\title{
RENOVATION OF THE OLD MUD VILLAGE OF SADOS, SAUDI ARABIA
}

\author{
KHALID A. AL SAUD \\ College of Architecture and Planning, King Saud University, Saudi Arabia
}

\begin{abstract}
Sados is a small village located $70 \mathrm{~km}$ north-west of Riyadh, the capital city of Saudi Arabia. Sados is one of the oldest settlements in Saudi Arabia. The mud village Sados has a compact fabric and is surrounded by a high wall and protection corner towers. The streets are very narrow and many bridges connect the houses facing each other. The village has about 85 houses within an area less than $10000 \mathrm{~m}^{2}$. Mud, sundried mud bricks, and wood are the primary materials that were used to build the village. During the last 25 years, the village was abandoned and became a ruin. Fortunately, the local authority managed to find funds to renovate the village and a full documentation was available. The renovation project was divided into four phases. Three were completed and the fourth phase is still pending. Unfortunately, the future function of the village was never discussed. The main objectives of this research paper are: first, to emphasize the indigenous architecture of the central region of Saudi Arabia; second to demonstrate renovation efforts and whether they were conducted in accordance with the original design; and third, to discuss alternatives regarding the future function of the village. Literature, previous studies and reviews, site visits and interviews were the main source of information. Some differences between the original village design and the village after renovation were noticed. Sados became one of the unique places to preserve the architectural heritage of Saudi Arabia. The conclusion was to modify the village function to be a mix use of traditional hotel, heritage museum and folk market, in an effort to attract tourism.
\end{abstract}

Keywords: renovation, mud architecture, rehabilitation, historical architecture.

\section{INTRODUCTION}

\subsection{Sados location and history}

Sados is a small mud village sited in the middle of a palm-tree oasis located $75 \mathrm{k}$ north-west of the city of Riyadh. It is considered one of the oldest settlements in Saudi Arabia. Al Hamdani [1] who lived in the 10th century mentioned in his book Sifat Jazirat Al Arab that Sados has a stone palace which was built for King Sulaiman. The British Col. Lewis Pelly [2] visited Sados in 1865 on his way to Riyadh. He mentioned in his book Journey to Riyadh that he saw ruins and a 20-ft high stone column, "Al Manarah", standing in the middle. Unfortunately, hundreds of years ago residents of Sados demolished the column to keep away strangers from coming to their village to see the column.

\subsection{Sados architectural character}

Sados is a small village surrounded by high walls and a few defense towers, like walls and towers of other surrounding towns and villages (Fig. 1). Unlike most of the villages in the central region of Saudi Arabia where the mosque and the market are centrally located, Sados mosque is located at the edge of the village and the open market located outside the village. All village houses comprise two floors and rarely one finds a house with an inner courtyard. There is one main street extending between the village's two gates. The main street divides the village in two halves and very narrow passages branch from the main street serving a few small neighborhoods. Most of the ground floor spaces are without daylight other than through 
the doors. The only fresh water source within the village is a well located at the edge of the village and sanitary utilities are very few. All construction materials are available from nearby sources. Mud, sundried mud-bricks, hay, stone, wood, palm tree leaves and gypsum plaster are the main construction materials.

\subsection{Climate and surrounding environment}

The palm-tree oases surrounding the village reduce the harsh desert's hot and dry climate which prevails most of the year. Little rain falls during the winter season, requiring flood irrigating palm-tree farms and raising the ground water level sustaining water in springs and wells.

\subsection{Population}

Until 1980 the village was alive and $90 \%$ of buildings were in acceptable condition (Al-Yaum [3]). Residents since then have migrated to newly built concrete houses in Sados or in other neighboring towns searching for work and a better standard of living. Sados village had then eighty-five houses (Hanke [4]) within less than $10,000 \mathrm{~m}^{2}$ accommodating about 600 people.
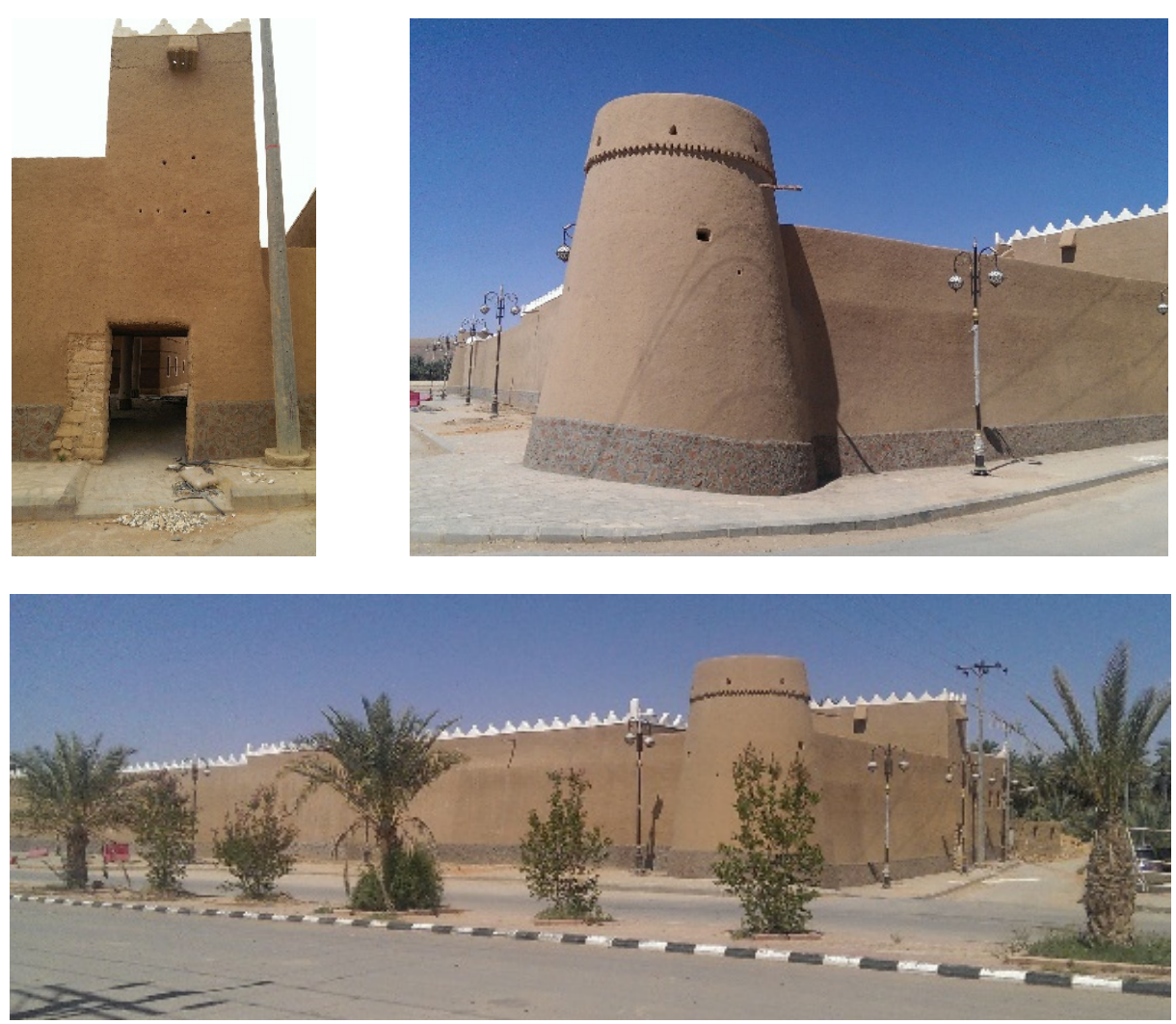

Figure 1: Views of the renovated Sados village surrounding by high walls and defense towers. 


\subsection{Pre-renovation village condition}

The village was considered as a heritage site. Unfortunately, the mud houses deteriorated due to rain and the village became a ruin. It was very difficult afterwards to define the portion of walls, streets, spaces and the architectural details.

\subsection{Renovation project}

Fortunately, in 2014 the local municipality with the help and support of the Saudi commission for tourism and national heritage managed to secure funds for Sados's renovation project. The project consists of four stages costing more than five million Euros. The municipality managed until now to complete three stages. Unfortunately, financial difficulties delayed the start of the fourth stage and almost half of the village is still to be renovated. Since the village was a ruin, the renovation process followed the drawings and documentation done by Dr. Christopher Maria Hanke [4] who worked for nine years to produce detailed documentation of Sados, which was incorporated into his Doctoral dissertation.

Unfortunately, the renovation project has no clear vision with regard to the future function of the village, something that now is under discussion.

\section{RESEARCH OBJECTIVES}

The objectives of this research are as follows:

- To emphasize the mud indigenous architecture heritage in terms of design, character, construction system and building materials.

- To demonstrate renovation efforts, carried out to restore the village and whether the renovation project was executed in accordance to the available documentation.

- To discuss alternatives regarding the future function of the village and put forward some recommendations.

\section{RESEARCH METHODOLGY}

Four steps were adopted to conduct the research and achieve its objectives:

1 Literature review of references, articles and previous researches related to old Sados.

2 Site visits to Sados to collect information and check the renovation progress.

3 Analysis of the collected information regarding the research objectives.

4 Discussion of the research outcomes and recommendations.

\section{INFORMATION GATHERING}

Books that are related to the history of Sados, documentation and drawings of Sados, and information regarding the renovation project in terms of cost and phases were collected.

Three field visits to Sados before renovation and three visits after renovation were conducted. The visits covered the execution and completion of the phases of renovation.

\section{ANALYSIS}

5.1 Emphasizing the indigenous architecture heritage

Mud villages in Saudi Arabia represent the pre-oil era. Since the discovery of oil, the shape and fabric of the Saudi cities, towns and villages had changed completely. Wealth and 
prosperity transferred people to live in modern urban environment. Most of the mud towns and villages have been either demolished or abandoned. Recently, awareness regarding the importance of preserving old mud towns and villages is growing due to the facts that they represent an era when the local living environment was sustainable. Many environmental lessons can be derived from old mud villages, especially regarding climate adaptability.

Sados village with its unique plan and intense urban fabric differs from other surrounding villages. Mosque and market are not centrally located and almost none of the houses has courtyard. Apparently, security and poverty both have influence on the general shape of the village and sizes of houses. The village was surrounded with a high gated wall protected with a few towers.

Sados is almost of rectangular shape extending from north to south. A main street penetrates the village from north to south connecting between the village two only gates. Secondary passages branch from the main street towards very small neighborhoods (Fig. 2).

Sados has 85 houses within an area of less than $10,000 \mathrm{~m}^{2}$. All of them are of two floors and many bridges connect between opposite houses (Fig. 3). Ground floors have no daylight and there are few windows. The village has limited and primitive sanitary facilities. Fresh water supply comes from wells located at the edge of the village.

The architectural details, vocabulary (doors, windows, paintings and ornamentation) and character of the village is very similar to that of surrounding villages (Fig. 4). The mosque design is a typically traditional except that the main prayer hall is located in the first floor (Fig. 5).

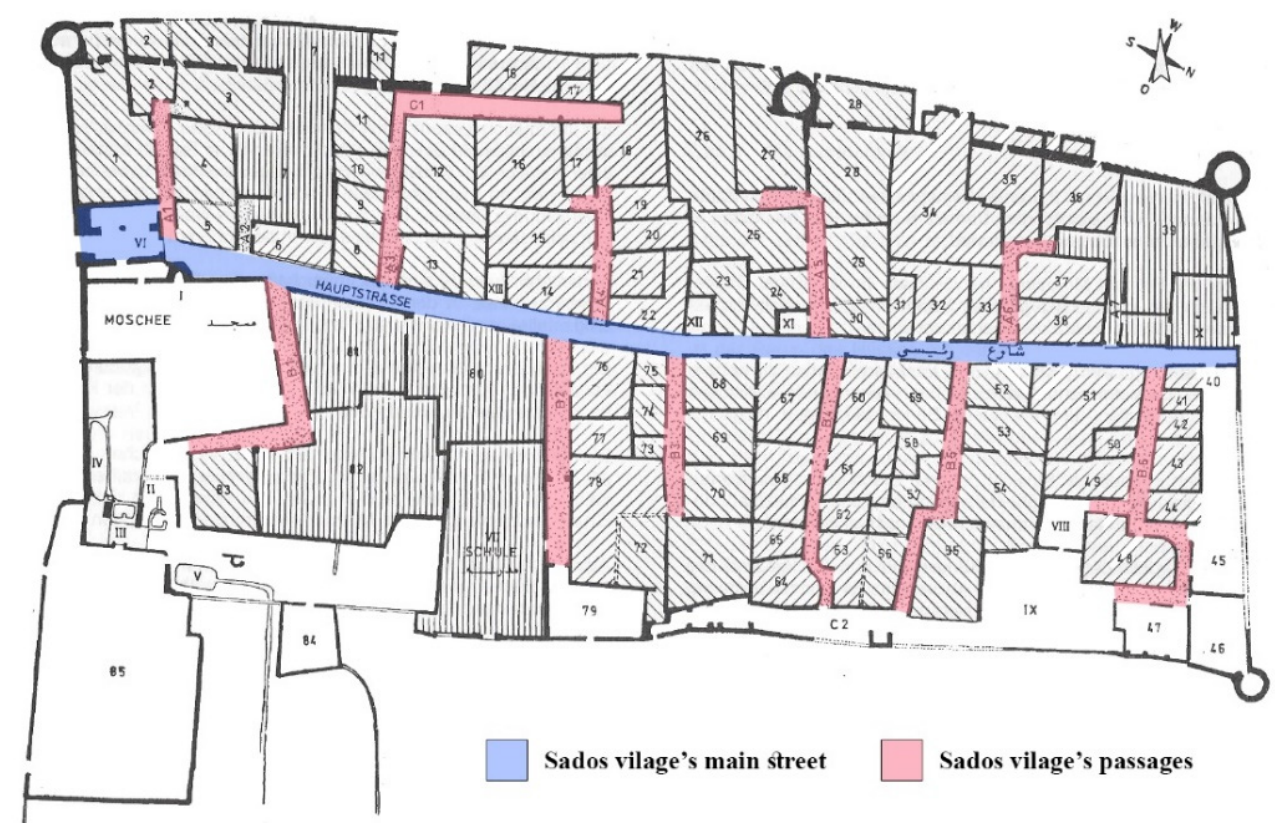

Figure 2: Sados village has one main street, and secondary passages branch from it towards very small neighborhoods. 

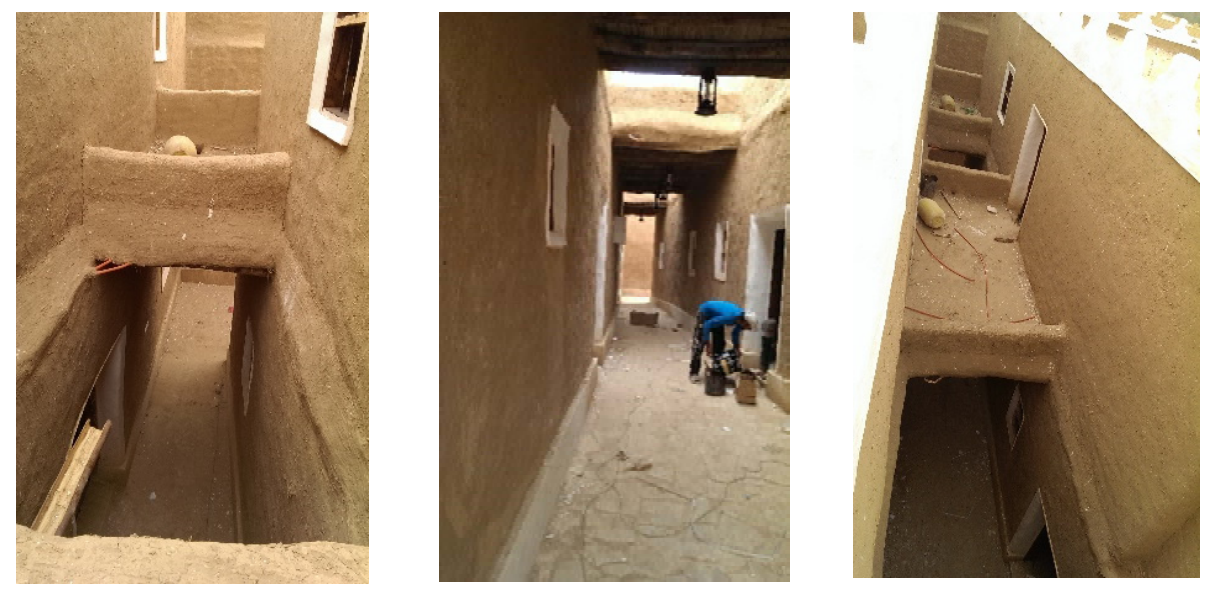

Figure 3: All of Sados village's houses consist of two floors and many bridges connecting the opposite house.
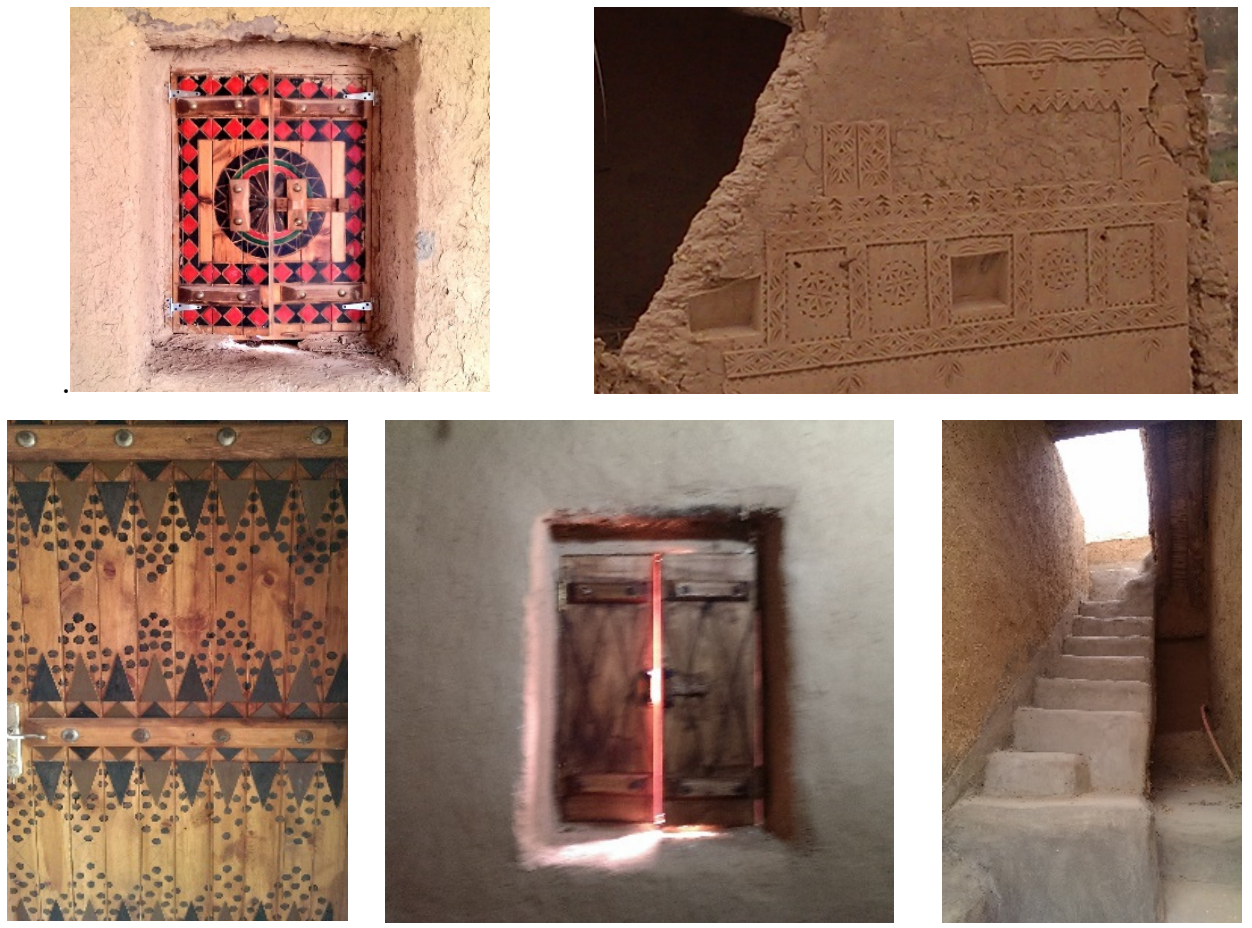

Figure 4: The architectural details in Sados village. 

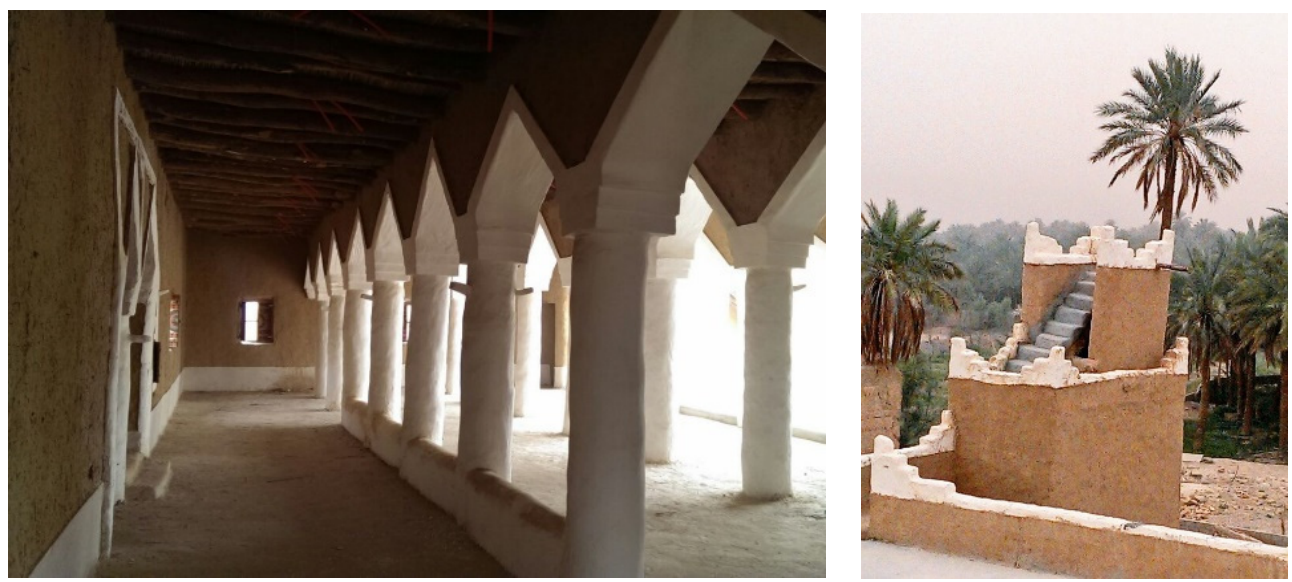

Figure 5: The mosque of Sados village.

Mud is the primary building material and is used to manufacture sundried bricks and prepare mortar and walls' plaster. Construction mud consists of a mix of soft dirt, hay and water. Hay works as a reinforcement material to strengthen the bond of the mud. The standard size of the mud bricks is $40 \times 25 \times 12 \mathrm{~cm}$.

Wood used for roofing is from locally grown high trees called "Athil". Athil is grown to work as a green fence to protect farms from dust storms. Palm tree leaves are used as a secondary roofing material (Fig. 6) and flat stones sometimes substitute palm tree leaves (Fig. 7). Cylindrical stones are used to build columns (Fig. 8) and rectangular ones for the lower parts of walls. Locally manufactured gypsum is used for plastering and decorating the walls of guest reception rooms (Fig. 9).
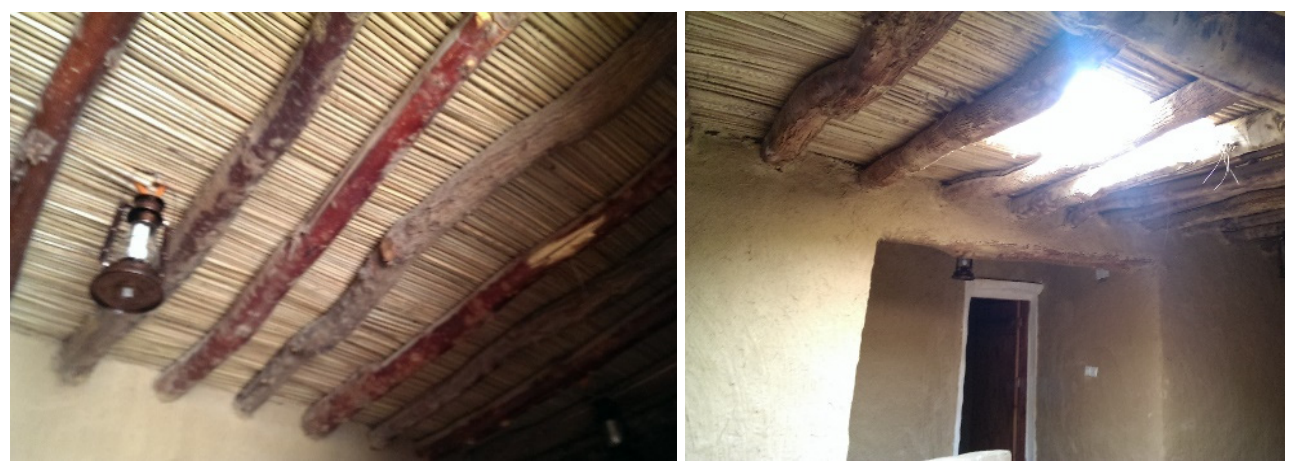

Figure 6: Palm tree leaves used as a secondary roofing material in Sados village's houses. 


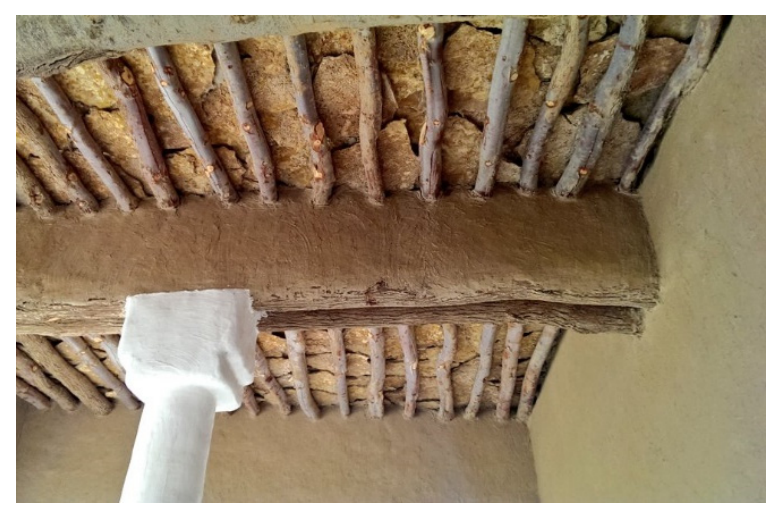

Figure 7: Sometimes flat stones are used as a secondary roofing material.
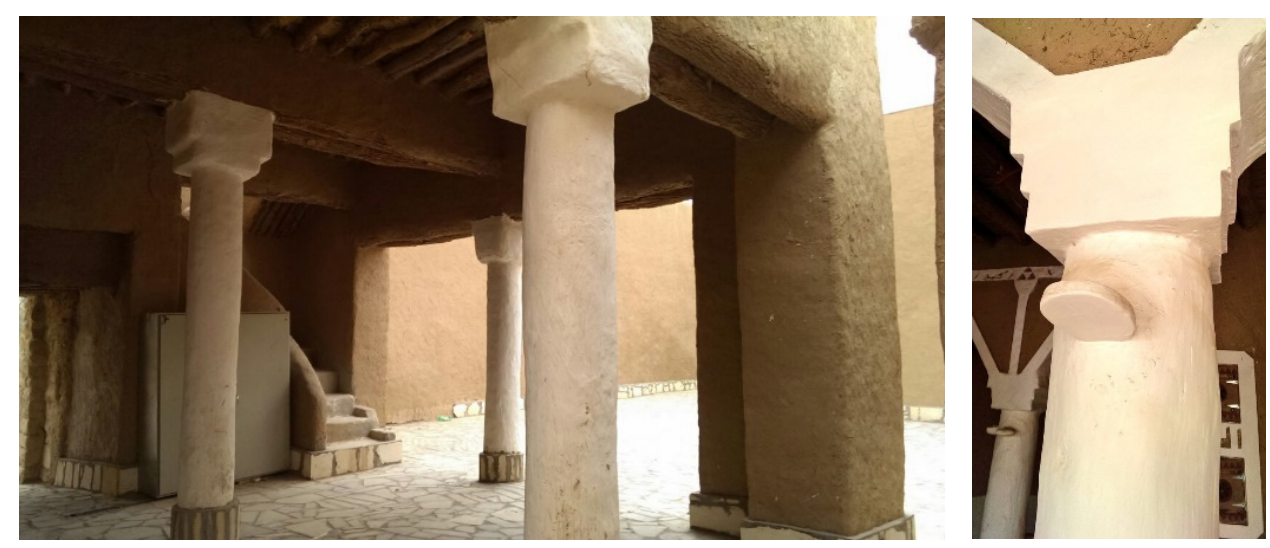

Figure 8: Cylindrical stones used to build columns.
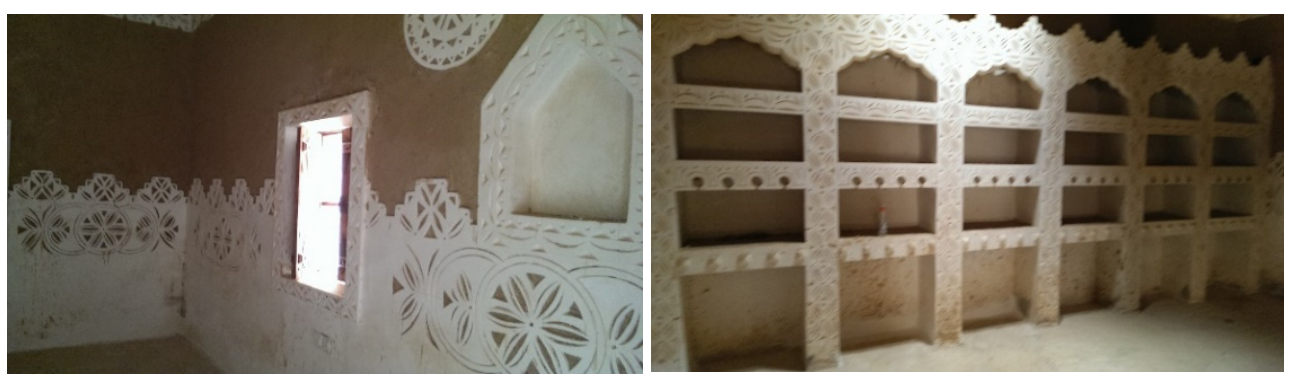

Figure 9: Locally manufactured gypsum is used for plastering and decorating parts of the walls.

Construction started by preparing on site mud bricks which were dried for few days before they could be used. Fig. 10 shows some construction stages and details. 

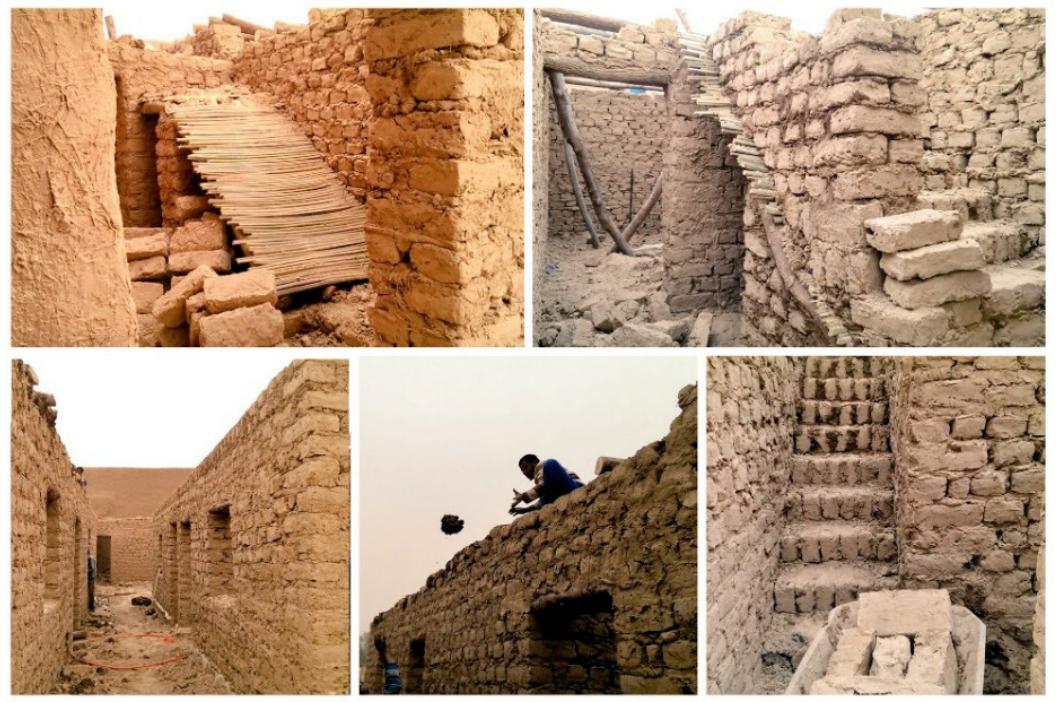

Figure 10: Construction stages of Sados village.

\subsection{Renovation efforts}

Three phases of renovation out of four were completed (Fig. 11). However, stage four is the largest among all phases and it encompasses the eastern side of the village. The already renovated parts of the village include defense walls, towers, main gates, village mosque, and many houses. Stage four is delayed due to financial difficulties (Fig. 12).

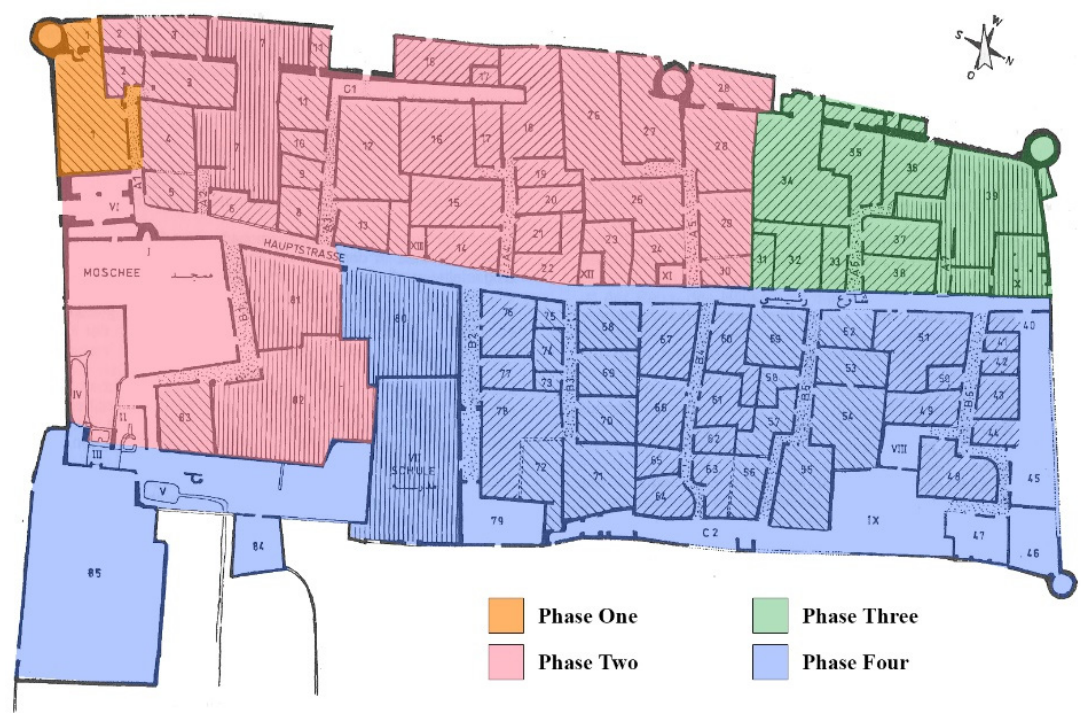

Figure 11: The four phases of Sados village renovation project. 


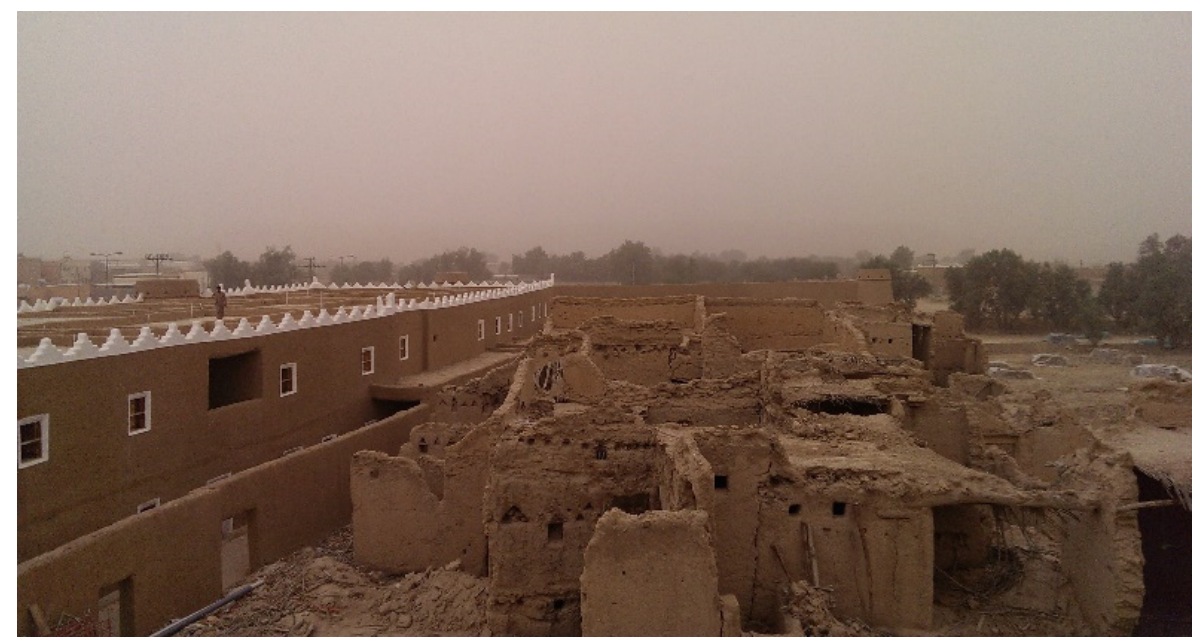

Figure 12: The difference between the parts that were renovated and those which were not.

The renovation of Sados in general was conducted in accordance with the available documents prepared by Dr. Hanke with some changes. A few houses were not rebuilt to create a small plaza near the main gate (Fig. 13). Also, the design of two houses were modified to create one reception hall. Fig. 14 shows the differences between what was documented and what was executed.

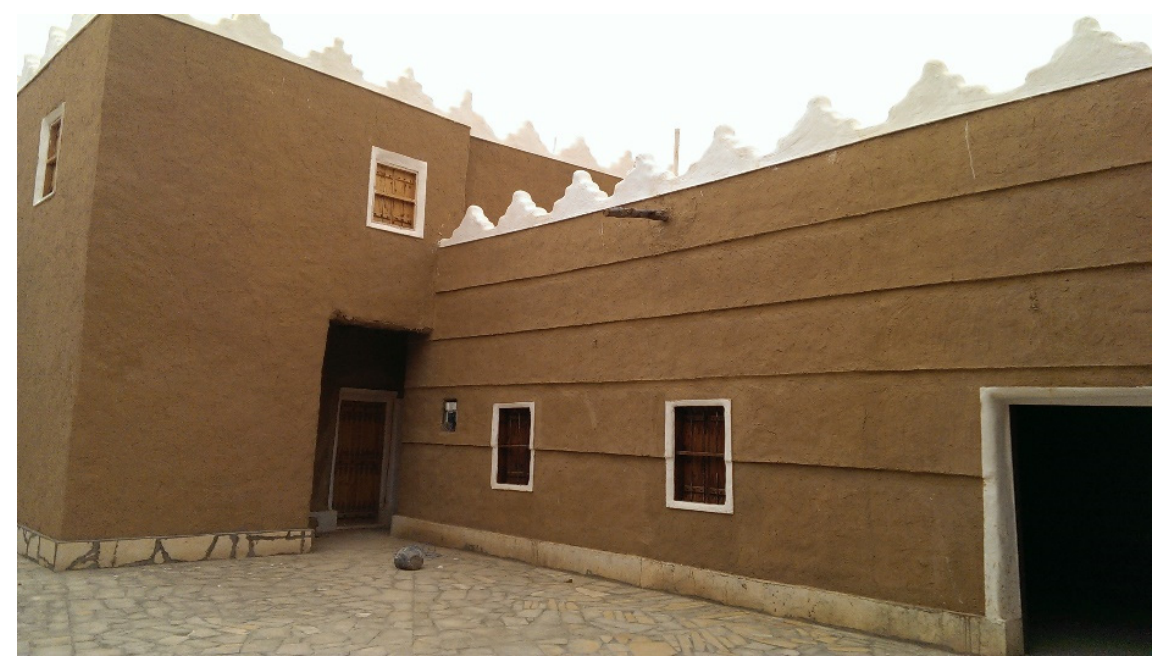

Figure 13: A reception hall and a small plaza were added to the new design of Sados. 


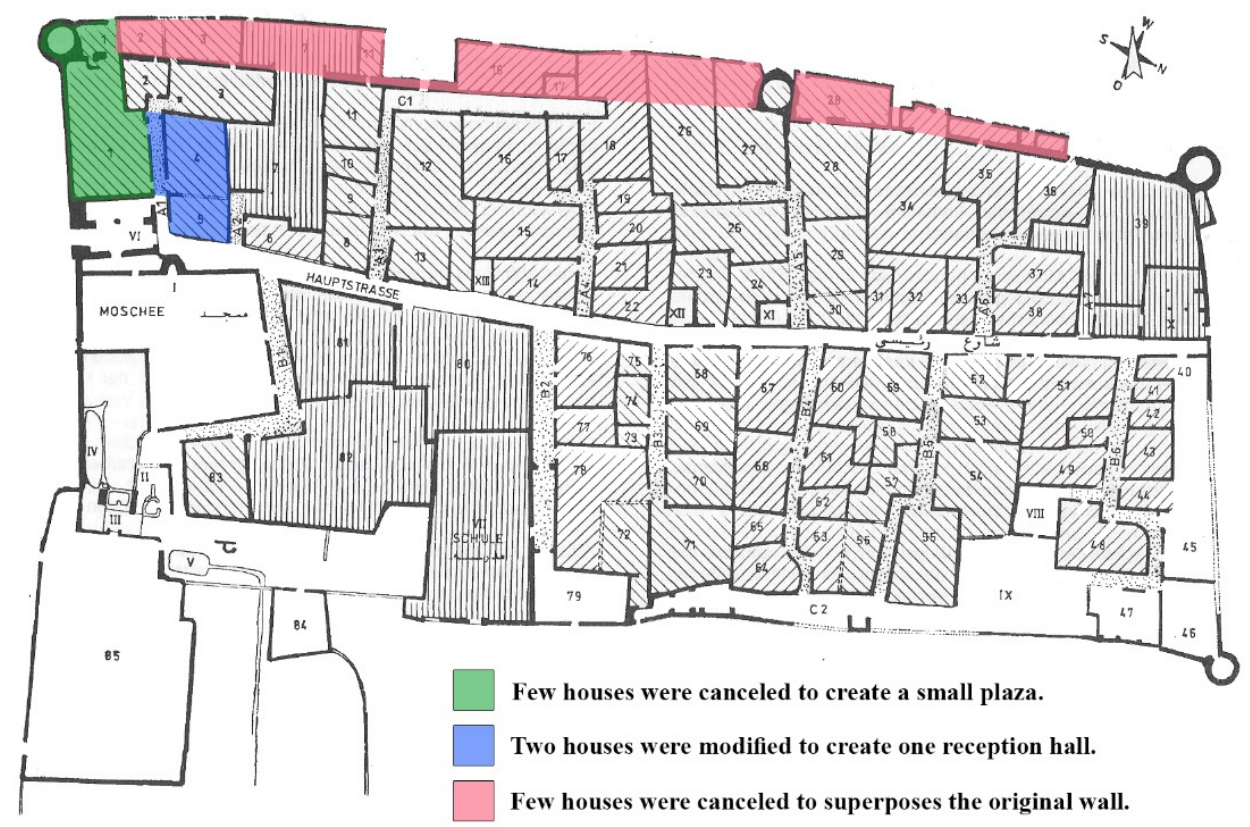

Figure 14: The differences between what was documented and what was executed in Sados village renovation project.

\subsection{Village future function}

No clear vision is available with regard to the future of the village after renovation, but three scenarios have been proposed as follows:

1 Bringing back the inhabitants.

2 Converting the village to a national heritage museum.

3 Converting the village to multiple functions: traditional hotel, restaurant, heritage museum and folk market.

Since the original inhabitants of the village migrated thirty years ago, there are strong doubts about the feasibility of the first alternative. In addition, village houses in terms of home services and infrastructure are not suitable for permanent residence.

The second alternative is feasible except that the village spaces are more than that required for the traditional exhibits. The third alternative which mixes and integrates several functions appears to be the most feasible option which could bring reasonable financial returns.

\section{CONCLUSION}

The renovation of Sados has created various opportunities. The village is considered one of the unique places that preserves the architectural heritage of the central region of Saudi Arabia. By modifying the village spaces various touristic functions such as traditional hotel, traditional restaurant and cafes, folk market and traditional performances it is hoped to attract local and foreign tourists. 


\section{SUGGESTIONS}

The author has suggested to the General commission for tourism and national heritage and the local municipality to revise the fourth phase of renovation in order to modify and develop the design of the village to accommodate some of the proposed functions.

\section{REFERENCES}

[1] Al Hamdani, Alhasan bin Ahmad, Sefat Jazerat Al Arab, Mohammed Al Akwaa: Riyadh, Dar Al Yamamah, 1977 (in Arabic).

[2] Pelly, L., Rehlat min Al Kuwait ela Al Riyadh, Ahmad Iybsh: Damascus, Dar Qutaiba, 2004.

[3] Al-Yaum, Riyadh, Saudi Arabia, www.alyaum.com/article/3123125. Accessed on: 24 Feb. 2014.

[4] Hanke, C.M., Qari:at Sadu:s, der Technischen Universitat Kaiserslautern, Dissertation. 